\title{
INTEGRATING CHRISTIAN LIVING AND INTERNATIONAL MANAGEMENT
}

Author:

Tobias Brügger ${ }^{1^{*}}$

Louise Kretzschmar ${ }^{2}$

\section{Affiliation:}

${ }^{1} \mathrm{PhD}$ student, Centre for Ethics, Zurich

${ }^{2}$ Theological Ethics, Department of Philosophy, Practical and Systematic Theology, University of South Africa

\section{Correspondence to:}

Tobias Brügger

Email:

Tobias.bruegger@ethik.uzh.ch

\section{Correspondence to:}

Louise Kretzschmar

Email:

Kretzl@unisa.ac.za.

\section{Postal address:}

PO Box 392, Pretoria 0003, South Africa

\section{Dates:}

Accepted: 01 Jun. 2015

Published: 01 Sep. 2015

How to cite this article: Brügger, T. \& Kretzschmar, L., 2015, 'Integrating christian living and international management', KOERS - Bulletin for Christian Scholarship 80(1), Art. \#2206, 15 pages. http:// dx.doi.org/10.19108/ koers.80.1.2206

\section{Copyright:}

(c) 2015. The Author(s).

Published under the

Creative Commons

Atribution License.
This article investigates how Christian living and international management practice can be integrated. We argue that dualistic and reductionist conceptions of the relationship of faith and work can be observed in international management theory, and in some Christian-theological approaches to business ethics. Similarly, a separation between faith and work is adopted by certain management practitioners. However, such dualistic and reductionist conceptions are inadequate in the light of actual practice of international management. A case study revealed that international management theory and practitioners can be critiqued because of a lack of consideration of the connection between faith and management practice. A re-thinking of international management practice without the artificial separation of faith and practice is needed. This requires the development of a non-dualistic approach to Christian living and a combination of conceptual and empirical research to explore actual practice in international management contexts.

Keywords: Christian living, international management practice, separation between faith and work, non-dualistic approach to Christian living

$\ldots \ldots \ldots \ldots \ldots \ldots \ldots \ldots \ldots \ldots \ldots \ldots \ldots \ldots \ldots \ldots \ldots \ldots$

Hierdie artikel ondersoek die moontlikheid hoe ' $\mathrm{n}$ Christelike lewenswyse en internasionale bestuurspraktyk geïntegreer kan word. Ons redeneer dat dualistiese en onderwerpende opvattinge oor die verhouding tussen geloof en werk in internasionale bestuursteorie en in sommige Christelike Teologiese benaderinge tot sake-etiek waargeneem kan word. Net so word 'n skeiding tussen geloof en werk deur sekere bestuurspraktisyns ingeneem. Sulke dualistiese en onderwerpende opvattinge is egter onvoldoende in die lig van die werklike beoefening van internasionale bestuur. ' $\mathrm{n}$ Gevallestudie het geopenbaar dat internasionale bestuursteorie en praktisyns gekritiseer kan word vanweë ‘n gebrek aan die inagneming van die verbintenis tussen geloof en die bestuurspraktyk. 'n Heroorweging van internasionale bestuurspraktyk sonder die kunsmatige skeiding van geloof en beoefening is noodsaaklik. Dit vereis die ontwikkeling van ' $\mathrm{n}$ nie-dualistiese benadering tot die Christelike lewenstyl en ' $\mathrm{n}$ kombinasie van konsepsuele en empiriese navorsing om die feitelike praktyk in internasionale bestuurskontekste te ondersoek.

Sleutelwoorde: Christelike lewenswyse, internasionale bestuurspraktyk, skeiding tussen geloof en werk, nie-dualistiese benadering tot Christelike lewenswyse
* This article is based on T. Brügger's MTh dissertation in Theological Ethics, specialising in Christian leadership. It was completed within the department of Philosophy, Practical and Systematic Theology (University of the South Africa). Currently, he is a PhD student at the Center for Ethics at the University of Zurich, Tobias.bruegger@ethik.uzh.ch. 


\section{INTRODUCTION}

This article investigates how Christian living and international management practice can be integrated. We introduce several theoretical paradigms of the link between faith and work within international management theory and theological ethical approaches to business. In the second section that is based on an empirical case study, we analyse the views of management practitioners. In the third section, there is a discussion on what Christian living consists of and what its relevance is to management practice in an international context. We argue that theological business ethics is a valid mode of reflection, not only for moral issues in the business context, but also for the broader questions of the integration of faith and work. Below, the term 'faith' is used in a general sense, including basic beliefs and assumptions about reality. When we use it specifically, we refer to the 'Christian faith'.

\section{THEORETICAL PARADIGMS CONCERNING THE LINK BETWEEN FAITH AND WORK}

Several disciplines discuss the question of the relationship of the Christian faith or religion and management. These include international management theory, business ethics, and theology. In this article, we will focus on aspects of international management theory and theological ethical thought.

In international management theory, two main approaches can be identified, namely faith-exclusive and faith-inclusive approaches. The faith-exclusive approach is hostile to the integration of faith and management practice. Religious and ethical convictions and practices are understood as mere subsets of national culture, and their influence on management practice is considered to be negligible (Mead 2006). A result of this approach has been the separation of issues of faith and work.

This question of the lack of integration of faith and work has been addressed in several publications (Childs 1995, Lynn, Naughton \& VanderVeen 2009 \& Walker 2013). Observers describe the difficulties individuals experience when they seek to integrate faith and work (Nash \& McLennan 2001, Epstein 2002, Miller 2006; \& Van Loon 2000). Walker (2013:453) speaks of the 'largely bifurcated lives, with a near total separation' between faith and work.

Another approach is to construe international management theory in such a way that it is open to the integration of faith and management practice. Although we found no conceptions which fully integrated faith and management, several approaches offered access points to the integration of religion and management. One possible entry point is business strategy. Because of its normative element, strategy is not neutral. It addresses questions of what ought to be done (Kutschker \& Schmid 2006:797-819). Another access point can be found in the conception of management behaviour as being formed by a manager's perspective, mindset, worldview, and ethical convictions (Perlmutter 1965). A third access point is offered by the theme of co-operation. Group performance and co-operation require the development of a shared, normative understanding of the group process (Zeutschel 2003; Stumpf 2003). In sum, while there are faith-exclusive conceptions of international management, some aspects of international management are open to questions of faith and ethics.

With reference to current Christian business ethical thought, two particular versions of a separation of faith and work are discussed below as they are reflected in some of the literature and in the responses from particular interviewees in the Siemens case study. The first version is an understanding of Christian-ethical living as the mere application of ethical values (such as justice) that have been abstracted from a religious or other worldview, ${ }^{1}$ the second is a reduction of the function of ethical criteria to practice-limitation.

\subsection{Ethics as application}

In the first form of the faith-practice gap, faith is reduced to moral values that have been abstracted from a Christian worldview. Within a management context, Christian-ethical living is understood as the mere application or implementation of these abstract ethical standards. This Christian form of a faith-practice gap corresponds to a general separation between ethics and practice, in which the focus is on abstract ethical standards (which may or may not be deduced from faith). It is linked to a preoccupation with ethical entities such as norms, values, criteria, and principles. In this view, an ideal ethical sphere of standards exists in contrast to actual practice. Thus, practice has to be adapted or transformed by the application of ethical standards.

This idea of ethics as application can be found in a number of different approaches to business ethics. The business ethicist Nils Ole Oermann (2007:399f) argues that the implementation of ethical standards in business enterprises is the main ethical challenge of business. People who live ethically are thus engaged in adapting reality for the betterment of society. The manager and theologian Ulrich Hemel (2005:280-289) proposes the application of ethical 'minimum standards' (Mindeststandards) like trust, transparent communication, and the ethical imperative of strategy. He seeks to overcome the ethics-practice gap by combining ethical and managerial criteria. To lead an enterprise based on a specific strategy, for example, is an ethical as well as an economic imperative. Although Hemel argues for a combination of ethical and managerial criteria, the basic idea is that of a gap between an ideal sphere of standards and criteria, and the reality, to which they are to be applied.

Within the notion of ethics as application, the understanding of the role of faith differs. Oermann (2007:404) points to the hermeneutical function of the Christian faith in business ethics - a Christian perspective can explain human motivation and action, drawing on a theological anthropology.

\footnotetext{
1 It was the Enlightenment thinker, Immanuel Kant (1724-1803), who argued that morality could be separated from religion and that moral norms could be identified and applied on the basis of autonomous human reason (Kant 1947).
} 
For Oermann, such an anthropology can be expressed in a normative way, such as in a Protestant concept of justice or human dignity. Hemel (2007:154) argues that the role of the Christian faith in the business context is to offer an understanding of the world and of human beings, and it provides the motivation to live according to ethical standards (2007:281).

The value of the approaches of Oermann and Hemel is that they provide links between faith and work for moral understanding, the relevance of moral norms in the workplace and the motivation to live ethically in a work context. However, the weakness of Oermann's and Hemel's approaches is that they cannot account for the comprehensive and integrative character of Christian formation and living. The Christian faith becomes a 'partial, provincial affair' (Bonhoeffer 2005:57/42 ${ }^{2}$, see below).

Arthur Rich's Business and Economic Ethics (2006), contains two different attempts to overcome this basic notion of a contrast between reality and a normative sphere. First, he seeks to reconcile ethics and practice in the business context by arguing for the principle of a balance of two criteria - the ethical criteria of the humanly just ('das Menschengerechte') and the factual criteria of the economically rational ('das Sachgemässe'). According to him, what is not economically rational cannot be humanly just, and what is not humanly just cannot be economically rational (Rich 1992:174; 2006:70-75; Enderle 2010:58). However, the idea of application remains dominant in Rich's conception. While he seeks to reconcile normative ethical and economic standards, these standards are seen as ideals (a sphere of economic and ethical ideals) that need to be applied to the practical sphere.

Rich's second attempt draws on his specific understanding of the Christian faith. Christian living includes a normative claim of how we should live and a gift, that is, the empowerment to live up to those standards (1984:242f; see also 2006:113-116). This conception includes the idea of a separation between a real and an ideal sphere. Thus, although the idea of ethics as application remains important, it is, however, an ethics of application by receiving (2006:242).

The remaining dichotomy between the normative ideal and the actual reality is linked to Rich's attempt to distil out of the Christian faith some generally accepted criteria, which can be communicated and received universally (see also Hemel 2007:281). In Rich's view (2006:167), the criteria of the humanly just can be articulated in "a way that it can be understood, discussed, and applied even without the fundamental premises" of experience-based Christian convictions. Christian convictions are a resource for and substantiation of ethical criteria. Thus the humanly just is rooted in the Christ-event. The humanly just 'in its ethical concretion' (2006:121) is, however, not specifically Christian. It is a 'humanity based on the Christian faith' (2006:242), not a Christian humanity.

The value of this notion is that it creates an 'open' space where ethical matters can be debated by people who hold different views. However, from the perspective of the integration of faith

2 The second page number refers to the pagination of the German version (DBW 6) of Bonhoeffer's Ethik (1998). and work, the difficulty with this approach is that the ethical 'concretion' takes on the form of abstract universal criteria, which are separated from their particular Christian roots.

\subsection{Ethics as practice-limitation}

A second form of the faith-practice gap is the reduction of Christian ethics in business to a practice-limiting function. Practice-limitation does not positively inform, inspire or shape practice. It merely prescribes what should not be done, for instance, a business executive should not steal, cheat or practice bribery (Price 2008). In this approach, ethical convictions are a limiting framework, a fence that restricts, rather than a driving force that creates. Thus, the bulk of business practice becomes an area of adiaphora, of arbitrariness and ethical neutrality, framed by some moral borders. In such an approach, ethics is at the margins of business practice. Similar to the notion of ethics as application, this understanding is linked to a preoccupation with abstract ethical norms or values. In its Christian version, it can be observed in the popular emphasis on values, such as 'Christian values' or 'biblical values' (Hemel 2005; Bakke 1995). As the empirical case study will indicate, when ethical thought focuses on values that are abstracted from a particular worldview, it is likely that morality and faith will be seen as primarily practice-limiting.

To summarise, some openness towards the integration of faith and management is to be found in international management theory. However, the approaches of Oermann, Hemel and Rich to faith and work in theological business ethics advance the notion of a faith-practice gap. This gap takes the form of an understanding of Christian-ethical living as the mere application of ethical norms to business practice and/or the reduction of faith and ethical convictions to practicelimitation. While we agree that moral agency (or conduct) is important in work contexts, and that Christians ought not to engage in unethical practices, we hold that faith in business should not be reduced to mere morality or the application of moral values, nor should morality be reduced to a practicelimiting function.

\section{THE FINDINGS OF AN EMPIRICAL STUDY CONDUCTED WITH EXECUTIVES AT SIEMENS AG}

To explore the relationship between faith and international management, an empirical study was conducted in the context of an international product development and marketing project at the global headquarters of one of the Siemens business lines. The objectives of the empirical research were, to analyse the main practical problem areas in the project, to identify starting points for the improvement of the collaboration, and to explore the relation of faith and management practice in a key problem area (that of conflicting pricing strategies).

\subsection{The research design}

Semi-structured, one-on-one interviews were conducted (Mayring 2002:67-72), combining elements of narrative 
(Hopf 2000:349ff) and structured interviews ${ }^{3}$. The interviews were recorded digitally, transcribed, and analysed using an adapted Grounded Theory approach (Kuckartz 2007:72-82; Flick, von Kardoff \& Steinke 2000:475-84), with the aid of the software programme MAXQDA. The empirical study consisted of two phases. The objectives of the first set of interviews were to analyse the actual situation within the project, to identify key issues as starting points for the improvement of co-operation, and to obtain a preliminary indication of how the religious orientation of the interviewees influenced their practice. Nine Siemens managers were interviewed and data was collected about their background, work experience, values, religious views, culture and their involvement in the project. In the second set of interviews, four managers were interviewed. In this second phase, the objectives were to deepen the understanding of a key problem (that of conflicting pricing strategies) and to explore how the ethical convictions, basic assumptions and worldviews of the interviewees were relevant to the project. ${ }^{4}$

The interviewees were selected on the recommendation of the Siemens manager, who supervised the study on behalf of the company, based on their experience in international co-operation, knowledge of the project and their role within the project. The set of interviewees consisted of representatives working at locations in both the United States and Switzerland. The names of the participants were coded in the form of $\mathrm{P}_{1}$, $\mathrm{P} 2$, et cetera. The interviews were conducted in the interviewee's first language and recorded digitally, thereafter they were transcribed.

\subsection{Faith as disconnected from business practice}

Once the data had been collected, the managers' views on the relationship between faith and business practice could be identified. It was found that faith in the business context was mainly reduced to its moral dimension. Ethical convictions were abstracted from the basic worldviews of the interviewees, and also from the sphere of workplace practice. Moral conduct and business practice were juxtaposed and the conflict over the pricing strategy, which was a major problem in the project, was viewed as an ethically neutral problem. Several of the interviewees saw business practice as being formed by considerations of 'business need' or 'economic optimization'. In general, religious orientations were understood as influencing business practice indirectly, via the shaping of moral orientations. Ethical criteria were viewed as a limiting framework, rather than a driving force for business practice. For example, a Siemens manager who was a Catholic stated, 'I do not come to work in the morning with the idea in mind, 'today I want to do something good for humanity'. (...) The business aspect is predominant' (P7). This corresponded to the findings of the theoretical research discussed above, namely,

$3 \quad$ See Brügger (2010)

$4 \quad$ The interviews for phase 1 were conducted between 30 May and 22 July 2008. The interviews for phase 2 were conducted between 20 April and 10 Sept 2009. that the executives separated faith from work by reducing faith to morality and by adopting a practice-limiting, rather than a practice-forming, understanding of faith and work.

The data from phase 2 revealed the religious orientation of four of the executives: P6, an atheist, P8, a 'postmodern pluralist' (who expressed reservations about traditional religion), P7, a Catholic, and P9, an evangelical Christian. Interestingly, the atheist and the two Christian executives adopted a dualistic understanding of faith and work, based on the reduction of faith to practice-limiting ethical convictions. Neither of the Christians described their faith as practice-forming, or as a driving force for business practice.

\subsection{The openness of management practice to the integration of faith}

The data also revealed that one interviewee - P8, the 'postmodern pluralist'- questioned the neat separation of faith and management at a practical level. He further critiqued the seemingly neutral basis upon which decisions were made about the pricing strategy in the project.

Following phase 1 of the interviews, the pricing problem had been identified as the main practical challenge in the relevant project. Two organizational units (coded as MIL and MIT) were part of a larger business unit (coded as $\mathrm{H1} 1$, and involved in the development and marketing of a new set of products. MIT and MIL promoted opposing pricing strategies for the relevant products. The managers from MIL advocated a low-price strategy to increase their overall market share, while the managers from MIT promoted a high-price strategy to position the products at the high-end segment of their target market.

In contrast to the other interviewees, P8 (the 'postmodern pluralist') expressed his unease with a practice-limiting understanding of the role of faith in business. He tried to make sense of the relationship between faith, convictions, worldviews and business practice:

On the one hand it is easy to say: "No, there is not really a link". But I am sure they are linked somehow. But the question is how to - I would say it's not - I have never consciously thought: "Well, because of my worldview... I approach this particular problem in a certain way". But I can't help but think that it's somehow a factor (P8).

P8 seemed to be unsure about the relationship between faith and work practice, shifting from one position to another in the course of the interview. P8 also commented on the lack of information on which business decisions are sometimes made:

If you know all the information and you know it all as fact, then you can sit down and make a decision based on economy, or you can make a decision based on politics. But if you know all the information, you can choose a method of decision. One of the issues we have is, the information we have is, in some ways, guesses. We don't know - will the pricing for MIT products really come 
down? Should it come down? Should we be the first to lower it? Should we wait and react? This is a problem that the MIT product managers deal with. They don't have perfect information. You never have perfect information. We also, MIL, don't have perfect information (P8).

A key factor in the pricing problem was the lack of information, or a state of uncertainty. Hence, decisions based on reason and information could not always be made; executives sometimes had to act on guesses and assumptions. This is where basic assumptions, personal convictions and ethics definitely played a role.

In addition, the MIT and MIL entities adopted different business strategies, based on their organizational history and their particular marketing approach,

But I think that was a contributing factor to this pricing problem. What the history of MIT was building up, and how products are made, what their features and functions are and how they're priced to the market. Just as a little bit different way of looking at it than the way MIL always did it. You sell products and you price the value of that product, and not its membership in a system. (...) That is one of the big factors. And that becomes a factor in how it gets solved, too. Because we have two different strategies within $\mathrm{H} 1$ (P8).

Because of this explosive mixture of uncertainty and conflicting business strategies, P8 (from MIL) critiqued the management of MIT. In his view, the MIT management pretended to act on the basis of certainty and they denied the tentative character of the pricing strategy they were promoting,

And that was really my first exposure to the PM [product management] process here (...) as being a very structured, very professional way of looking at it, which was really, really good. ... And so they have a very pragmatic, systematic way of making assessments of how the effect of the system would be. And to me this was quite a challenge, because to me this was taking unknowns, putting them in a structure that looks official and looks like it is true, when it is fundamentally based on assumptions we can't know.

There's a certain belief in the process on the MIT side that you don't find on the MIL side. And to me that's - maybe that's a little wordplay to talk about beliefs, but how you make decisions is based on what you believe. And how you can manage what management believes - you can tell the story in a way, and put the facts behind it in a way, that you get the result that you're looking for (P8).

According to P8, MIT's method of developing a strategy based on a combination of economic analysis and assumptions was not a problem in itself. $\mathrm{P} 8$ recognised that his own situation was also characterized by uncertainty, assumptions and his view of the market,
My role in this was - I have to do the best I can to imagine - What do I really need to build up a full MIL solution? ... Assumptions! Without knowing what it might really be (P8).

P8 recognised the tentative status of the strategic analysis and conclusions reached by the management of MIT. But he criticised the MIT managers for denying their uncertainty and presenting their strategy as being the right one on the basis of 'economic facts'. P8's analysis of this conflict surrounding the pricing strategy acknowledges the interplay between basic assumptions and management practice. Business practice is performed in a context of uncertainty. Business decisions and strategies are therefore based not simply on facts, but also on guesses, assumptions, feelings, tentative analyses and decisions. Rather than acknowledging this state of uncertainty and the tentativeness of their analyses, managers are tempted to pretend that their views are incontrovertible and their practices are based on clear information. It is interesting to note that P9, one of the two Christians that were interviewed, was criticized by $\mathrm{P} 8$ for not stating the assumptions that underpinned his economic analysis.

P8's analysis of the pricing problem is a vivid example of the highly complex and multi-layered nature of business practice. Although P8 does not offer a clear explanation of the integration of faith and management practice, his analysis challenges the neat separation between the sphere of management practice and that of religious faith, ethical beliefs and basic assumptions about reality.

The empirical data thus exposed a paradox. On the one hand, it revealed that some managers, including Christians, separated faith from work. This was done by reducing faith to the application of ethical principles and by reducing ethical criteria to a practice-limiting function. On the other hand, the data revealed that the separation between faith and managerial practice was being questioned. The analysis of the pricing problem showed how deeply held convictions impacted practical decision making, even though this was not recognised by all the participants. The practitioners who adopted a dualistic understanding of faith and work, tended to deny or ignore the underlying convictions that influenced their actions. The empirical analysis did not lead to a 'solution' to the problem of the separation of faith and work. But it did reveal some of the practical problems that were caused by this separation, such as conflicts that arise as a result of presenting one's own views as economic truth, and failing to state the assumptions that underpin these views. Faith in the form of basic beliefs about reality influences business practice. Therefore, on a practical level, it is problematic to assume a radical gap between faith and practice. This separation of faith and practice corresponds to the inadequacy of the two theoretical faith-practice gaps identified earlier.

In the light of the empirical research, a link between faith and international management is not only found in a few areas, such as in business strategy or co-operation. If a state of uncertainty often characterizes management contexts in general ('you never have perfect information'), then 
management practice is never totally free of basic assumptions about reality. Management theory and practice are thus not 'objective' or 'neutral'. Thus, the search for more integrative and comprehensive conceptions of faith and management that can account for actual practice-formation in the business context does not amount to constructing a new, a 'religious' or 'faith-based' international management theory. Rather, it is an act of undoing the artificial, abstract separation that currently obscures actual practice-formation in international management contexts. It is an act of exploring management practice without the limitations of the dubious separation of faith and work.

\section{INTEGRATING CHRISTIAN LIVING AND MANAGEMENT PRACTICE}

In order to integrate the Christian faith and management, a non-reductionist, integrative conception of Christian living that takes account of practice-formation in management needs to be developed. Drawing on the fields of Christian ethics and spirituality, we describe Christian living as 'being led by the Spirit of God so that one can participate in the formation of Christ within a concrete context'. Christ is not only formed in individuals, but also in contexts and in groups, as Christ takes form 'among us'. This understanding offers a fresh and promising perspective on the formation of Christian managers and their role in practice-formation within business and management contexts. Below we draw on the thinking of Dietrich Bonhoeffer, Stanley Hauerwas, and Simon Peng-Keller because of their contribution to an understanding of the nature and importance of Christian formation. ${ }^{5}$ We draw on their discussions on Christian living precisely because the analysis of Christian approaches to business ethics in the first section of this article shows that the faith-practice dichotomy is linked to problematic, general understandings of the Christian faith. Thereafter, we sketch the implications of such a conception for a theological approach to international management.

\subsection{Ethics as the Spirit-led participation in the formation of Christ}

Although Dietrich Bonhoeffer does not discuss the business context in detail, ${ }^{6}$ his ethic provides a way of integrating Christian living and business practice because it avoids the abstraction and anthropocentricity of the notions of ethics as application and practice-limitation. Bonhoeffer's ethics ${ }^{7}$ emphasizes the reality of Christ in "our world" (2005:55/40) that is, the concrete context in which people live. Christian living is not concerned merely with the application of norms or principles "to our circumstances and our time" (2005:55/40).

$5 \quad$ Another approach in seeking to relate Christian ethics to matters of public concern is Nigel Biggar's ‘Barthian Thomism' (2011:107-112).

6 See Padelford (2011)

This brief outline of Bonhoeffer's approach to ethics is based on the Ethics Manuscripts "Christ, Reality, and Good" and "Ethics as Formation", which are published in Bonhoeffers "Ethics" (2005).
Rather, it is a matter of "participating in the reality of God and the world in Jesus Christ today" (2005:55/40).

Bonhoeffer argues that in order to understand and live a Christian ethic, one needs to undergo a paradigm shift away from a focus on oneself, to a focus on the reality of God revealed in the human being, Jesus Christ (2005:47-49/31-34). His Christological framework includes three aspects. First, Jesus Christ encompasses all of reality, namely the reality of God and the reality of the world (2005:54/39). Second, in the human being Jesus Christ, God entered and was revealed to the world (2005:49/33), and reconciled the world to himself (2005:61/46). Third, Christian ethics is concerned with "how this reality of God and of the world that is given in Christ becomes real in our world' (2005:55/40). It is important to note that for Bonhoeffer, the name of Jesus Christ is not a metaphor for a moral value such as love, but the name of a concrete person. Bonhoeffer's concern is the concrete human being, Jesus Christ, as he lived, was crucified, and rose from the dead (2005:93/80). The Christo-centricity of Bonhoeffer's approach can be noted on an epistemological level and as the ethical expression of Christian living.

Bonhoeffer argues that thinking in terms of two conflicting realms is predominant in 'traditional Christian ethical thought' (2005:55/41). Many subscribe to the notion of a fundamental contrast, or conflict between two realms, 'one Divine, holy, supernatural and Christian; the other worldly, profane, natural and unchristian' (Bonhoeffer 2005:56/41). ${ }^{8}$ However, this conflict has been overcome in the reconciliation between God and the world in the person and work of Jesus Christ. This new Christ-reality becomes manifest in the concrete lives of disciples. Bonhoeffer describes this realization as 'formation' (2005:96/84) and "participating in the reality of God and the world in Jesus Christ today" (2005:55/40). The key question of Christian ethics is thus, "how Christ may take form among us today and here' (2005:99/87). The form that Christ takes in believers is the practical expression of Christian living.

Three elements of Bonhoeffer's ethics are especially relevant to this article. First, there is a shift away from purely human effort and activity to being formed by Christ. Thus, Christian living is not a program one can implement, but a relationship, orientation and way of life into which one is drawn. Second, Christian living does not consist of ethical norms and values that can be abstracted from a Christian worldview or community, but rather that Christ is formed in the disciple and in the world. A third element drawn from Bonhoeffer's ethics relates to the way Christian ethics is lived and communicated. Bonhoeffer argues that since Christ has come, 'we cannot speak rightly of either God or the world without speaking of Jesus Christ. All concepts of reality that ignore Jesus Christ are abstractions' (2005:54/39). This reveals the emptiness of ethical 'values' as criteria detached from Christ and the Gospel. In contrast to the approach of the two Christian managers discussed earlier, in order to understand the relationship of Christian living and management practice, Christian living needs to be seen as a full

8 Bonhoeffer (2005:55/40-70/57) and Duchrow (1977) critique the common misunderstanding of Luther's 'two kingdoms' doctrine. 
participation in the formation of Christ in the business context. It is not enough to describe Christian living as adherence to abstract criteria such as so-called 'Christian values'.

A similar view of ethics is advocated by Stanley Hauerwas. He describes Christian living as the embodiment of the story of Jesus Christ. God is known through the story of the people of Israel and the story of Jesus Christ, his life, death and resurrection(Hauerwas1983:15).Itis an 'enactedstory'(1983:26), which humans are to hear, to tell and to live. The Christian faith is not a set of doctrines derived from the biblical stories, from which ethical norms are deduced and then applied, "There is no "point" that can be separated from the story. The narratives through which we learn of God are the point', says Hauerwas (1983:26). Christian living is thus not characterized by the mere application of norms, but by the embodiment of a story. Thus, the task of business ethics from a Christian perspective is to reflect on how the story of Jesus Christ can be embodied in the business context, without abstracting ethics from this story. While in Hauerwas's terminology, this can be misunderstood as a merely human activity, Bonhoeffer's phrase of 'participating in the formation of Christ' expresses more clearly the passive element in Christian living. The relationship between human effort and God's activity in Christian living and management practice can be further clarified by describing Christian living as Spirit-led.

The Holy Spirit is mentioned in Bonhoeffer's ethics in the context of the realization of what is already real, namely in the current formation of Christ, which has already come into the world (2005:50/34; 99/87). It is by the Spirit of God that Christ takes on form 'today and here'. Pneumatology and spirituality are thus crucial for an adequate understanding of the relationship between God's activity and human activity in Christian living. Simon Peng-Keller (2010:12-14) describes two usages of the term spirituality. On the one hand, it can be used theologically-anthropologically, referring to the human spirit. On the other hand, it can be used in a pneumatological sense, referring to the Spirit of God. These two definitions of spirituality have different starting points but they can be combined. When one is 'led by the Spirit of God', the active, human and ethical element engages with the pneumatological element. This active presence of the Holy Spirit is a driving force, through which the attitudes and practices of a Christian life are moulded (2010:14). Christian living is then understood as the art of learning to live a Spirit-led life (2010:39). ${ }^{9}$ Paradoxically, Christian living is both receiving the gift of God and a corresponding human practice. In Christian living, God's action has primacy over human effort. This is why Bonhoeffer describes Christian living as 'passive'. But its passivity does not exclude 'powerful thoughts' and 'joyful deeds' (2005:337/341):

Precisely those who act in the freedom of their very own responsibility see their action as both flowing into and springing from God's guidance. agency in its relation to the Spirit in his Theologische Ethik (2002:120137).
Free action, as it determines history, recognizes itself ultimately as being God's action, the purest activity as passivity (Bonhoeffer 2005:226/225).

With respect to management practice, important Christian business ethical questions are, 'How Christ may take form in the practice of management', and 'how managers may let themselves be led by the Spirit to participate in this formation'? Based on this understanding, the task of business ethics from a Christian perspective is not to deduce abstract normative values and call for their application, but to explore and describe the relationship of human agency and God's activity in a concrete business or management context.

\subsection{Conclusion: Towards a non-reductionist, integrated conception of business ethics}

On the level of a conception of managerial practice, two aspects of the outcome of this attempt to integrate Christian living and international management may be tentatively described by using the terms 'orientation' and 'freedom'.

Orientation is based on the primacy of God's action over human efforts. As Christian living is characterized by a Spirit-led participation in the formation of Christ, awareness of God's action leads to a liberating God-orientation, which can both undergird and inspire human practice. Christ takes form in concrete contexts (Bonhoeffer), and not in abstract norms or universal theories. As human beings are led by the Spirit of God (Peng-Keller), they can embody the story of Jesus Christ (Hauerwas), in the contexts where they live and work. Thus, Christ may take form within human beings and in business contexts as managers become more orientated to God and aware of the contribution of others in the workplace. In terms of the empirical study discussed earlier, such a manager can enable colleagues to become more aware of their own and wider cultural perceptions of reality and work, and the impact that these have on practical decision making in the workplace.

Freedom means that managers are no longer preoccupied with abstract or practice-limiting ethical norms and criteria, and are able to experience the freedom of being formed in Christ and able to be creative within a management context. Such managers can be freed from the restricted understandings of reality and morality held by secularism and reductionist forms of management practice. They can develop a deeper, spiritual understanding of the world, relationships, human nature and decision making. The theological question with respect to international management can be stated as the question of how 'free, responsible and creative human action, as it impacts on international management practice, may recognize itself ultimately as being God's action, the purest activity as passivity' (see Bonhoeffer 2005: 226/225).

These theoretical explorations may be combined with the empirical study of concrete contexts, where the formation of Christ may occur. The above discussion on the empirical study revealed dualistic understandings of faith and work, and sharpened the awareness of the authors of this article of the nonintegrative thinking patterns in international management 
theory and in theological thinking about business practice. Instead of simply discussing abstract normative ethical criteria, such as norms and values, the consideration of broader approaches to Christian living ${ }^{10}$ may offer business ethics a fresh perspective on management practice. There may be also Christian executives who separate faith and management practice at an intellectual level, but 'unconsciously' develop forms of Christian practice. By using both interviews and observation of their actual practice, it would be possible to compare the data drawn from their reflections with the researcher's observation of their practice, in order to develop a richer account of how their practice is shaped by the Christian faith.

In these ways, our understanding of Christian living in the context of international management theory and practice can be both deepened and extended.

Key concepts: International management, faith and work, Christian living, formation, participation, theological business ethics.

\section{LIST OF REFERENCES}

Bakke, D., 1995, 'Values don't work in business', in M. Stackhouse, et al (eds.), On moral business, pp. 713-717, Eerdmans, Grand Rapids.

Biggar, N., 2011, Behaving in public: How to do Christian ethics, Eerdmans, Grand Rapids.

Böhm, A., 2007, 'Theoretisches Codieren: Textanalyse in der Grounded Theory', in U. Flick, E. von Kardorff, \& I. Steinke (reds.), Qualitative Forschung: Ein Handbuch, pp. 475-485, Rowohlt, Reinbek bei Hamburg.

Bonhoeffer, D., 1992, Ethik, Dietrich Bonhoeffer Werke. Sechster Band. Kaiser, Gütersloh.

Bonhoeffer, D., 2005, Ethics, Dietrich Bonhoeffer works, Volume 6, transl. R. Krauss, C.C. West and D.W. Stott, Fortress, Minneapolis.

Bourdieu, P., 2010, Distinction: A social critique of the judgement of taste, Routledge Abingdon.

Brügger, T., 2010, Freedom and Orientation: A Christian Contribution to International Management. Unpublished MTh Dissertation, University of South Africa, Pretoria.

Childs, J., 1995, Ethics in business: Faith at work. Fortress, Minneapolis.

Duchrow, U., 1977, Lutheran churches: Salt or mirror of society? Lutheran World Federation, Geneva.

Enderle, G., 2010, ,Arthur Richs Bedeutung für die Entwicklung der Wirtschaftsethik', Zeitschrift für Wirtschafts- und Unternehmensethik, 11(1), 51-65.

Epstein, E., 2002, 'Religion and business: The critical role of religious traditions in management education', Journal of Business Ethics, 38, 91-96.

Fischer, J., 2002, Theologische Ethik: Grundwissen und Orientierung, Kohlhammer, Stuttgart.

Hauerwas, S., 1983, The peaceable kingdom: A Primer in Christian Ethics, Notre Dame, University of Notre Dame.

Hemel, U., 2005, Wert und Werte. Ethik für Manager: Ein Leitfaden für die Praxis, Carl Hanse, München.

Hopf, C., 2000, 'Qualitative Interviews - ein Überblick', in U. Flick, E. von Kardorff, \&I. Steinke (reds.), Qualitative Forschung: Ein Handbuch, pp. 349-360, Rowohlt, Reinbek bei Hamburg.

Kant, I., 1947, The moral law: Groundwork of the metaphysics of morals, transl. H. Paton, Hutchinson's University Library, London.

Kuckartz, U., 2007, Einführung in die computergestützte Analyse qualitativer Daten, VS, Wiesbaden.

Kutschker, M. \& Schmid, S., 2006, Internationales Management, Oldenbourg, München.

Lynn, M., Naughton, M. \& VanderVeen, S., 2009, 'Faith at work scale (FWS): Justification, development, and validation of a measure of Judaeo-Christian religion in the workplace', Journal of Business Ethics, 85, 227-243.

Maclntyre, A., 2007, After virtue: A study in moral theory, University of Notre Dame, Notre Dame.

Mayring, P., 2002, Einführung in die qualitative Sozialforschung: Eine Anleitung zu qualitativem Denken, Beltz, Weinheim.

Mead, R., 2005, International management: Cross-cultural dimensions, Blackwell, Malden, MA.

Mellor, P. \& Shilling, C., 2010, 'The religious habitus: Embodiment, religion, and 
sociological theory', in The New Blackwell Companion to the Sociology of Religion, pp. 201-220, Blackwell, Chichester.

Miller, D., 2006, God at work, The history and promise of the Faith at Work movement, Oxford University, New York.

Nash, L. \& McLennan, S., 2001, Church on Sunday, work on Monday: The challenge of fusing Christian values with business life, Jossey-Bass, San Francisco.

Oermann, N. O., 2007, Anständig Geld verdienen? Protestantische Wirtschaftsethik unter den Bedingungen globaler Märkte, Gütersloher Verlagshau, Gütersloh.

Padelford, W., 2011, Bonhoeffer and business ethics, BorderStone, Mountain Home AR.

Peng-Keller, S., 2010, Einführung in die Theologie der Spiritualität, WBG, Darmstadt.

Perlmutter, H., 1965, 'L'entreprise internationale', Revue Economique et Sociale 23(2), 151-165.

Perlmutter, H., 1969, The tortuous evolution of the multinational corporation, Columbia Journal of world business, 4(1), 9-18.

Price, T.L., 2008, Leadership ethics: An introduction, Cambridge University, New York.

Rich, A., 1984, Wirtschaftsethik: Grundlagen in theologischer Perspektive, Gerd Mohn, Gütersloh.

Rich, A., 1992, Wirtschaftsethik II: Marktwirtschaft, Planwirtschaft, Weltwirtschaft aus sozialethischer Sicht, Gerd Mohn, Gütersloh.

Rich, A., 2006, Business and economic ethics: The ethics of economic systems, Peeters, Leuven.

Stumpf, S., 2003, ,Interkulturelle Arbeitsgruppen', in A. Thomas, E.-U. Kinast, \& S. Schroll-Machl (reds.), Handbuch Interkulturelle Kommunikation und Kooperation, Band 1: Grundlagen und Praxisfelder, pp. 341-353, Vandenhoeck \& Ruprecht, Göttingen.

Walker, A., 2013, 'The Relationship between the integration of faith and work with life and job outcomes', Journal of Business Ethics, 112, 453-461.

Zeutschel, U., 2003, Interkulturelles Projektmanagement, in A. Thomas, E.-U. Kinast, \& S. Schroll-Machl (reds.), Handbuch Interkulturelle Kommunikation und Kooperation, Band 1: Grundlagen und Praxisfelder, pp. 307-323, Vandenhoeck \& Ruprecht, Göttingen.

\section{ACKNOWLEDGEMENTS}

\section{Competing interests}

The authors declare that they have no financial or personal relationship(s) that may have inappropriately influenced them in writing this article. 